\title{
Dung survey bias and elephant population estimates in southern Mozambique
}

\author{
Pieter I. Olivier, Sam M. Ferreira and Rudi J. van Aarde* \\ Conservation Ecology Research Unit, Department of Zoology \& Entomology, University of Pretoria, Pretoria 0002, South Africa
}

\begin{abstract}
We used dung surveys to estimate population size and extracted an age structure from boli diameters for the elephants living in the Maputo Elephant Reserve. Our estimate was based on published defecation rates, dung decay rates, distance-sampling techniques and 1,672 dung piles encountered on 204 line-transects. The reserve had at least 311 (95\% CI: 198-490) elephants at a density of 0.60 (95\% CI: 0.38-0.94) per $\mathrm{km}^{2}$. However, observer bias reduced effective strip widths and inflated estimates and their confidence limits. The age structure extrapolated from dung measurements indicated few newborn calves compared with other populations. To detect population changes of $2-5 \%$ at $80 \%$ power, dung surveys should be carried out every second year for the next 20 years using 100 transects of at least $500 \mathrm{~m}$ each. Comparison with a 1995 dung survey suggests that the population is stable and that previous fears of a major population decline during the civil war have no foundation.
\end{abstract}

Key words: density, dung counts, dung decay, elephant population size, Maputo Elephant Reserve

\section{Résumé}

Nous avons eu recours à l'étude des crottes pour estimer la taille de la population des éléphants qui vivent dans la Réserve à éléphants de Maputo et pour en déduire une structure d'âges à partir du diamètre des crottes. Notre estimation se basait sur des publications sur le taux de défécation, le taux de décomposition des crottes, des techniques d'échantillonnage à distance et sur 1,672 tas de crottes rencontrés sur 204 transects linéaires. La réserve comptait au moins 311 éléphants (IC 95\%: 198-490), à une densité de 0,60 animal $/ \mathrm{km}^{2}$ (IC 95\%: 0,38-0,94). Cependant, le biais dû à l'observateur réduisait la largeur

*Correspondence: E-mail: rjvaarde@zoology.up.ac.za réelle des bandes et gonflait les estimations et les limites de confiance. La structure d'âges extrapolée à partir de la mesure des crottes indiquait qu'il y avait peu de nouveaunés par rapport aux autres populations. Pour déceler les changements de population de $2-5 \%$ avec une puissance de $80 \%$, les études de crottes devraient se faire tous les deux ans au cours des 20 prochaines années, en utilisant 100 transects d'au moins $500 \mathrm{~m}$ chacun. La comparaison avec une étude des crottes réalisée en 1995 suggère que la population est stable et que les craintes émises auparavant d'un déclin majeur de la population pendant la guerre civile n'avaient aucun fondement.

\section{Introduction}

Several different survey techniques provide information that forms the basis of population estimates for African elephants (Loxodonta africana Blumenbach) (DouglasHamilton, 1996). For elephants that live in dense woodlands and forests, scientists often use dung surveys. Such surveys may provide estimates of abundance that are comparable with those that count elephants directly (Barnes, 2001) and as precise as estimates derived from aerial surveys (Barnes, 2002).

Population estimates based on dung counts require estimates of the number of dung piles per $\mathrm{km}^{2}$, the number of piles produced by an elephant in a day and the rate at which dung piles decay (Barnes \& Jensen, 1987). Dung surveys can also provide additional population information. For instance, dung boli diameters allow for the assignment of ages to elephants (Morrison et al., 2005) that may be converted to population age structures (Jachmann \& Bell, 1984; Reilly, 2002). Such age structures and independent estimates of fecundity can be used to calculate intrinsic population growth rates using the procedures suggested by Udevits \& Ballachey (1998). 
A key to the success of dung surveys is the level of precision that may be required to deduce population growth rates. Narrower confidence intervals imply greater precision of estimates. From published information, we know that sampling intensity and observer bias can influence estimates of dung pile density (Jachmann \& Bell, 1984). We also know that habitat types and boli sizes affect decay rates (Barnes, Asamoah-Boateng \& AgyeiOhemeng, 2006) and that limited visibility in forests makes it difficult to observe elephants defecating to estimate defecation rates (Barnes, 2001). In addition, the presumed lower detectability and faster decay rate of small boli could skew age frequencies. Dung surveys therefore may be of limited use unless designed to meet criteria that will return reliable demographic profiles without challenging the practicalities of undertaking such surveys.

We investigated the reliability and practicality of dung surveys based on a case study in the Maputo Elephant Reserve (MER) in southern Mozambique. We estimated the size of the elephant population, derived an age structure and addressed some sources of error associated with dung surveys. We also reviewed the literature on defecation and dung decay rates, and then estimated habitat-specific decay rates and dung pile densities in the MER. We evaluated the effect of sampling intensity on our estimates and used a power analysis to determine the frequency of surveys required to detect population changes.

\section{Material and methods}

\section{Study area}

The MER covered an area of $800 \mathrm{~km}^{2}$ in southern Mozambique $\left(26^{\circ} 25^{\prime} \mathrm{S}, 32^{\circ} 45^{\prime} \mathrm{E}\right.$, Fig. 1). The reserve was unfenced but for an electric fence of about $30 \mathrm{~km}$ along the western boundary that may have protected farmers from elephant raids (De Boer \& Ntumi, 2001). Here summers (October-March) were hot and wet and winters (April-September) were relatively cool and wet. Annual rainfall varied from 690 to $1000 \mathrm{~mm}$ (Direccao Nacional de Florestas e Fauna Bravia, 1997). The reserve is located in a biodiversity hotspot (Küper et al., 2004) and the vegetation included sand-, swamp- and coastal dune forests, open and closed woodlands, grasslands as well as reed beds. Sand forests are endemic to the region (Van Wyk \& Smith, 2001) and may be threatened by elephant activities (Guldemond \& Van Aarde, 2007). The woodlands had a closed and layered canopy with dense undergrowth.
Sparsely spaced mature trees and a prominent grass sward dominated the open woodlands.

The elephants of the MER are secretive and spend most of their time in the sand forests (De Boer et al., 2000; Ntumi et al., 2005), either foraging to accommodate the lower quality of browse, or to seek refuge following the historic poaching pressures (De Boer et al., 2000), or to escape from the high direct solar radiation typical of the region (Kinahan, Pimm \& Van Aarde, 2007). These elephants seldom forage on the grass and flood plains during the day and apparently do so mostly at night (De Boer et al., 2000). They were therefore not frequently encountered.

\section{Data collection and analysis}

For our analysis, we relied on published defecation rates that we collated along with decay rates noted elsewhere in Africa (Table 1). Fresh dung placed in sand forests $(n=59$ dung piles spaced $5 \mathrm{~m}$ apart in three quadrants), open woodlands ( $\mathrm{n}=51$, three quadrants) and grasslands ( $\mathrm{n}=36$, two quadrants) during April 2006 allowed us to estimate habitat-specific dung decay rates. For this, we collected fresh Stage A dung piles (following the classification of Barnes \& Jensen, 1987) throughout the MER. We used a tape measure to determine the circumference of boli in these piles and moved them to the different quadrants where stages of decay as described by Barnes \& Jensen (1987) were recorded at irregular intervals over a period of 147 days.

We used the models of Laing et al. (2003) to estimate dung decay rates. To determine whether large and small boli decayed differently, we separated dung piles of adults ( $\geq 42 \mathrm{~cm}$ in circumference) from those of sub-adults $(<42 \mathrm{~cm})$ (Jachmann \& Bell, 1984). We compared the number of days that it took for large boli $(\mathrm{n}=23)$ to reach Stage E (Barnes \& Jensen, 1987) or be absent, with those of small boli ( $\mathrm{n}=38$ ) using a $t$-test (Sokal \& Rohlf, 1995).

We estimated decay rates for all boli combined and defined dung piles ranging from Stage A to Stage D of decomposition (Barnes \& Jensen, 1987) as surviving and present, while those at Stage E or completely gone, were considered absent and not surviving. The decay quadrants were inspected during April, June, July and August. For analytical purposes, surviving dung piles were recorded as 1 and absent piles as 0 . We fitted three logistic decay models (Laing et al., 2003) through maximum likelihood (Edwards, 1972; Microsoft Excel macro from Hood, 2005) to these 


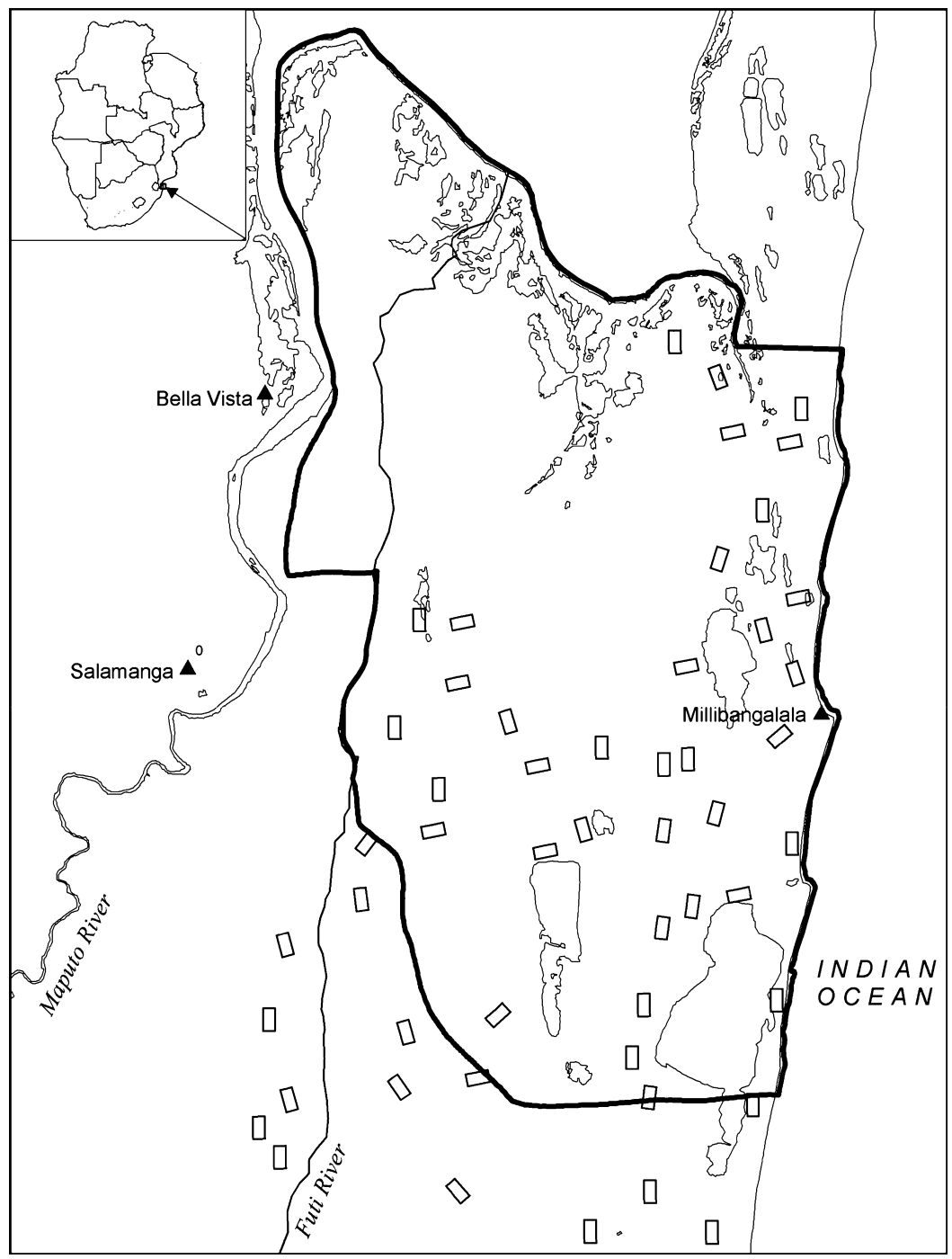

Fig 1 Map of the Maputo Elephant Reserve showing the park boundary (thick black line), rivers and lakes as well as the line transects used in the survey (squares) throughout the reserve and adjacent areas data and used $R^{2}$-values to choose the model that best represented the habitat-specific dung decay at our study site. These models allowed us to estimate the average time to decay, i.e. when $50 \%$ of the dung piles have disappeared (Laing et al., 2003). Variances in habitat-specific decay rates were calculated through Monte Carlo simulation (Gentle, 1943) using the error structure of coefficients in the models already obtained through maximum likelihood.

To estimate dung density, three counting teams counted dung piles while on foot during September 2006 along $98 \mathrm{~km}$ of line-transects $(\mathrm{n}=204)$, each with a maximum length of $500 \mathrm{~m}$ (Fig. 1). Each survey team comprised two observers. A cluster of four transects (at least $250 \mathrm{~m}$ apart in a square design) were placed at equal intervals along the existing road network of the MER. Our unpublished satellite tracking data suggested that elephants in the MER did not avoid roads. We used a GPS (Garmin Etrex; Garmin International Inc., Olathe, KS, USA) to mark the beginning and end of each transect. Observers noted every dung pile that they encountered and measured the perpendicular distance to the transect using either a rangefinder (Impulse; Laser Tech Inc., Engelwood, CO, USA) or tape measure. As the MER comprises a mosaic of different landscape types, a homogenous transect was seldom encountered. We thus recorded the GPS positions of changes in the vegetation along a transect. This allowed us to estimate transect length within a vegetation type as well as habitat-specific dung densities. 
Table 1 Wet and dry season defecation rate (dung piles per day) and decay rates collated for 17 study areas across Africa

\begin{tabular}{|c|c|c|c|c|c|c|c|}
\hline \multirow[b]{2}{*}{ Study area } & \multicolumn{3}{|c|}{ Defecation rates } & \multicolumn{3}{|c|}{ Days to decay to level $\mathrm{E}$} & \multirow[b]{2}{*}{ Reference } \\
\hline & Dry & Wet & Unknown & Dry & Wet & Unknown & \\
\hline $\begin{array}{l}\text { Queen Elizabeth } \\
\text { National Park }\end{array}$ & - & - & 17.0 & - & - & 160 & Wing \& Buss (1970) \\
\hline Tsavo National Park & - & 37.7 & - & - & - & - & Coe $(1974)^{\mathrm{a}}$ \\
\hline Rua National Park & 12.0 & 32.0 & - & - & - & - & Barnes $(1982)^{b}$ \\
\hline Bia National Park & - & - & - & - & - & 80 & Short $(1983)^{c}$ \\
\hline Kasungu National Park & 15.7 & - & - & - & - & - & $\begin{array}{l}\text { Jachmann \& Bell } \\
(1984)^{\mathrm{d}}\end{array}$ \\
\hline Tai National Park & - & - & 18.0 & - & - & 80 & Mertz (1986) \\
\hline Santchou Reserve & - & - & 20.0 & - & - & - & Tchamba $(1992)^{\mathrm{e}}$ \\
\hline Nazinga Game Ranch & 14.1 & 27.2 & - & - & - & 165 & Jachmann (1991) \\
\hline Lope Reserve & - & - & - & - & - & 81 & White (1995) \\
\hline Gabon & - & - & 19.7 & - & - & 44 & Barnes et al. $(1997)^{\mathrm{f}}$ \\
\hline Kahuzi-Biega National Park & - & - & 19.8 & - & - & 43 & Jefferson et al. $(1997)^{\mathrm{g}}$ \\
\hline $\begin{array}{l}\text { Manovo-Gounda St Floris } \\
\text { National Park }\end{array}$ & 12.2 & 16.6 & & & & & Ruggiero $(1992)^{\mathrm{h}}$ \\
\hline Maputo Elephant Reserve & 14.0 & 20.0 & & & & & De Boer et al. (2000) \\
\hline Bossematie Forest Reserve & 16.6 & 18.1 & & & & & $\begin{array}{l}\text { Theuerkauf \& } \\
\text { Ellenberg (2000) }\end{array}$ \\
\hline $\begin{array}{l}\text { Banyang-Mbo Wildlife } \\
\text { Sanctuary }\end{array}$ & - & - & - & $\begin{array}{l}123 \pm 30 \\
(\mathrm{n}=318)\end{array}$ & $\begin{array}{l}89 \pm 25 \\
(\mathrm{n}=552)\end{array}$ & - & $\begin{array}{l}\text { Nchanji \& Plumptre } \\
(2001)^{\mathrm{i}}\end{array}$ \\
\hline Parc National des Virunga & & & & 90.9 & 100.8 & $\begin{array}{l}55 \pm 12 \\
(\mathrm{n}=75)\end{array}$ & $\begin{array}{l}\text { Mubalama \& } \\
\text { Sikubwabo (2002) }\end{array}$ \\
\hline Shimba Hills National Park & - & - & 19.0 & - & - & 125 & Litorho (2003) \\
\hline
\end{tabular}

Plus or minus values denote $\mathrm{SD}$ and $\mathrm{n}=$ sample size.

${ }^{\mathrm{a}}$ No day-night or age differences.

${ }^{\mathrm{b}}$ Bulls only.

${ }^{c}$ Used Wing \& Buss (1970) estimate of defecation rate, decay only observed for max 80 days.

${ }^{\mathrm{d}}$ No significant difference between sexes.

${ }^{\mathrm{e}}$ No significant defecation difference between seasons.

fUsed estimates obtained from bootstrapping Tchamba's (1990) defecation rates and Barnes \& Barnes (1992) decay rates.

'Used Tchamba's (1990) defecation rates, the decay rate includes two wet seasons and one dry season decay sample.

${ }^{\mathrm{h}}$ No significant differences between sexes, significant difference between seasons.

${ }^{\mathrm{i} D r y}$ and wet season decay rates differ significantly (Nchanji \& Plumtre, 2001).

We evaluated three potential sources of survey error. We first evaluated if detection differed between counting teams by calculating the effective strip widths covered by each team using Distance 5.0 Release 2 (Thomas et al., 2005), hereafter referred to as Distance. We then used Distance to estimate population sizes using published defecation rate, estimated decay rate and dung density for each counting team.

We investigated sampling intensity as a second source of error by assessing how an increase in transect length would change the total number and the 95\% confidence intervals of estimates. To evaluate boli size as a source of error, we measured boli circumferences while walking line transects and calculated a detection function for these different sizes of boli using Distance.

To compare our estimate with previous estimates and guesses, we collated published and unpublished estimates of the same population.

Estimating individual ages. We searched the MER for fresh signs of elephants and followed these until we found intact boli. We then measured the circumference of a minimum of 2 and a maximum of 4 boli per dung pile and used the average to estimate the age of an individual elephant based on the model of Morrison et al. (2005). 
Dung pile density, elephant density and population estimate. We estimated dung pile densities and 95\% confidence intervals for the sand forests, open woodlands and grasslands using Distance. Distance combined habitatspecific density estimates to calculate a total density and its $95 \%$ confidence interval. We used the average wet season defecation rate that we collated from published studies and our own habitat-specific decay rates to estimate elephant densities and abundance within the three landscape types following the model of Laing et al. (2003). Distance allowed these rates and their variances as input variables. In the same way, separate estimates were calculated for each different counting team in each different habitat. To evaluate the effect of effective strip widths (and therefore observer bias) on our estimates, we calculated ten separate estimates for strip widths ranging from $1 \mathrm{~m}$ to more than $10 \mathrm{~m}$. For instance, the first estimate only included dung piles recorded within $1 \mathrm{~m}$ of the transect, the second only recorded dung piles within $2 \mathrm{~m}$ of the transect and so on (1-9 m), until the final estimate, which was made up of all recorded dung piles irrespective of strip width. In addition, we calculated the width of the $95 \%$ confidence interval for each of these estimates and compared the width of the $95 \%$ confidence intervals to the effective strip widths.

We also evaluated the effect of sampling intensity on our estimates by performing 100 separate analyses using Distance as described above. These analyses were performed on randomly selected transects that made up distances that ranged from 13,000 to $96,000 \mathrm{~m}$ covered throughout the MER and included transects conducted by the three counting teams and transects within the different vegetation types. This yielded 100 population estimates with 95\% confidence intervals (CI) that were then related to transect lengths.

Earlier estimates of the MER's elephant population are not comparable with ours except for a dung density estimate obtained in 1995 by De Boer et al. (2000). We used the defecation rate and habitat-specific decay rates of our study and applied it to the dung pile densities recorded by De Boer et al. (2000) to obtain a population estimate and its confidence interval for 1995. An estimate of exponential growth rate and its variance followed Caughley (1977) by applying a Monte Carlo simulation (Gentle, 1943) using the estimates and their 95\% confidence intervals for 1995 and 2006.

We defined the sampling (intervals and period) needed to detect future upward $(2-5 \%)$ or downward $(2-5 \%)$ trends in elephant numbers within the MER using TRENDS (Gerrodette, 1993). We assumed a linear decline or increase and set the coefficient of variation (CV) at $46.95 \%$ based on the results from our estimates (the standard error was calculated as $\mathrm{SE}=\mathrm{CL} / 2$, and coefficient of variation as $\mathrm{CV}=\mathrm{SE}$ /estimate). The power tests were one tailed and we set $\alpha=0.02$ following Barnes (2002) and Gibbs, Droege \& Eagle (1998). We defined a Power of $>80 \%$ as sufficient to detect $2-5 \%$ changes in population growth (Gerrodette, 1993).

Age structure. Following the assignment of ages from boli diameters (Morrison et al., 2005) estimated from our measured circumferences, we grouped elephants into 1 -year age classes up to 15 years of age, with all individuals above 15 years of age in one age class. We could not distinguish sexes from boli features and assumed an equal sex ratio up to 15 years of age (Moss, 2001). In this analysis, we only included dung boli measured for breeding herds and excluded boli deposited by lone bulls.

\section{Results}

\section{Defecation rates}

Based on our literature review, elephants across Africa defecated 16.6-37.7 times per day during the wet season, but only 12.0-16.6 times per day in the dry season (Table 1). In the MER, rainfall is relatively high throughout the year and defecation rates here may therefore be typical of that noted for wet seasons elsewhere. We calculated an average defecation rate of 25.3 ( \pm SD 8.5, $\mathrm{n}=17$ studies) based on the published wet season rates and used this value to estimate population density.

\section{Dung decay rates}

Our estimates of decay rates varied between the landscape types, with the fastest rate in the open woodlands (115 days, 95\% CI: 91-139), followed by the grasslands (124 days, 95\% CI: 91-155) and the sand forests (148 days, 95\% CI: 111-184). These were thus similar to those noted (43-167 days) for other study sites (see Table 1). The decay rates of small and large boli were similar $(t=0.18$; d.f. $=59 ; P=0.43)$.

\section{Dung pile densities}

We covered 36, 29 and $33 \mathrm{~km}$ of transects in the sand forest, open woodlands and grasslands, respectively, and 
found the highest dung pile density in sand forests $(3,629$ piles per $\mathrm{km}^{2}$, 95\% CI: 2381-5529). The open woodland had 1,111 (95\% CI: 654-1886) and the grassland, 148 (95\% CI: 68-312) piles of dung per $\mathrm{km}^{2}$ (Table 2).

A half-normal cosine detection model was selected for the sand forests $(\mathrm{AIC}=4875)$ and grasslands $(\mathrm{AIC}=$ 413), while a half-normal cosine detection model with two adjustment factors was selected for the open woodlands $(\mathrm{AIC}=2195)$.

The survey teams, landscape types and the size of the dung boli influenced detectability. Team 1 survey yielded an estimate of 298 (95\% CI: 188-475) elephants while the surveys of team 2 and team 3 gave estimates of 578 (95\% CI: 336-1026) and 374 (95\% CI: 226-640) elephants, respectively (Table 3). Survey teams missed 11\%, 19\% and $3 \%$ of all dung piles encountered on the 13, 15 and 16 sub-sample transects, respectively, that were conducted while being accompanied by an independent observer. Population estimates and estimates of confidence limits were sensitive to effective strip widths; narrow effective strip widths yielded high estimates with wide confidence intervals, while wide effective strip widths yielded lower estimates with narrower confidence intervals (Fig. 2). We prefer the estimate with the widest effective strip width as an indicator of population size because it was based on our complete data set.

Total transect length had no effect on our estimates. Estimates ranged from 194 to 667 elephants, with 92\% of the randomly calculated estimates falling within the $95 \%$ CI of our total estimate (Fig. 3a). In our study, increased survey intensity did not affect estimates. However, the percentage confidence interval calculated for different transect lengths reached an asymptote at 51,000 $\mathrm{m}$ of transects (Fig. 3b).

Detection probability was not a function of boli size and a half-normal cosine model was most appropriate for both small $($ AIC $=632)$ and large $($ AIC $=1165)$ boli - the model parameters were similar.

\section{Elephant density and numbers}

Elephants occurred at a density of 0.60 (95\% CI: 0.380.94 ) elephants per $\mathrm{km}^{2}$ across the $518 \mathrm{~km}^{2}$ of the MER that we sampled. The highest elephant density (0.97 elephants per $\mathrm{km}^{2}$, 95\% CI: 0.63-1.49) occurred in the sand forests. Densities in open woodlands and the grasslands were 0.38 (95\% CI: 0.23-0.63) and 0.05 (95\% CI: 0.02$0.10)$ elephants per $\mathrm{km}^{2}$, respectively. When corrected for area, these results yielded 234 (95\% CI: 152-360) elephants in the sand forests, 73 (95\% CI: 44-121) in the open woodlands and 4 (95\% CI: 2-9) in the grasslands. The total population thus was estimated at 311 (95\% CI: 198-490) elephants (Table 2). When the variables used in our study (decay and defecation rates) were integrated with the dung pile densities obtained by De Boer et al. (2000), elephant densities of 1.23 (95\% CI: 0.80-1.88), $0.48(0.29-0.79)$ and $0.44(0.18-0.88)$ elephants per $\mathrm{km}^{2}$ were calculated for the sand forests, open woodlands and grasslands, respectively (Table 2). These amounted to a total population estimate of 425 (95\% CI: 264-679).

The confidence intervals for our estimate represented a coefficient of variation of $46.95 \%$. Inclusion of this value

Table 2 Dung pile densities and population estimates (95\% confidence intervals) derived from the line transect survey conducted during August 2006 and dung pile densities and population estimates (95\% confidence intervals) recalculated from De Boer et al. (2000) for a survey conducted in 1995

\begin{tabular}{|c|c|c|c|c|c|c|}
\hline & \multicolumn{2}{|l|}{ Sand forest } & \multicolumn{2}{|l|}{ Open woodland } & \multicolumn{2}{|l|}{ Grassland } \\
\hline & 1995 & 2006 & 1995 & 2006 & 1995 & 2006 \\
\hline Area $\left(\mathrm{km}^{2}\right)$ & 241 & & 190 & & 87 & \\
\hline Days to decay & $148(111-184)$ & & $115(91-139)$ & & $124(91-155)$ & \\
\hline Transect length (km) & 4.6 & 36 & 9.4 & 29 & 4.6 & 33 \\
\hline $\begin{array}{l}\text { Dung pile density } \\
\text { per } \mathrm{km}^{2}\end{array}$ & $\begin{array}{l}4600 \\
(3100-6600)\end{array}$ & $\begin{array}{l}3629 \\
(2381-5529)\end{array}$ & $\begin{array}{l}1400 \\
(800-2500)\end{array}$ & $\begin{array}{l}1111 \\
(654-1886)\end{array}$ & $\begin{array}{l}1300 \\
(600-2900)\end{array}$ & $\begin{array}{l}148 \\
(68-312)\end{array}$ \\
\hline Population estimate & $296(193-453)$ & $234(152-360)$ & $91(55-150)$ & $73(44-121)$ & $38(16-76)$ & $4(2-9)$ \\
\hline $\begin{array}{l}\text { Total population } \\
\text { estimate (1995) }\end{array}$ & $425(264-679)$ & & & & & \\
\hline $\begin{array}{l}\text { Total population } \\
\text { estimate (2006) }\end{array}$ & $311(198-490)$ & & & & & \\
\hline
\end{tabular}




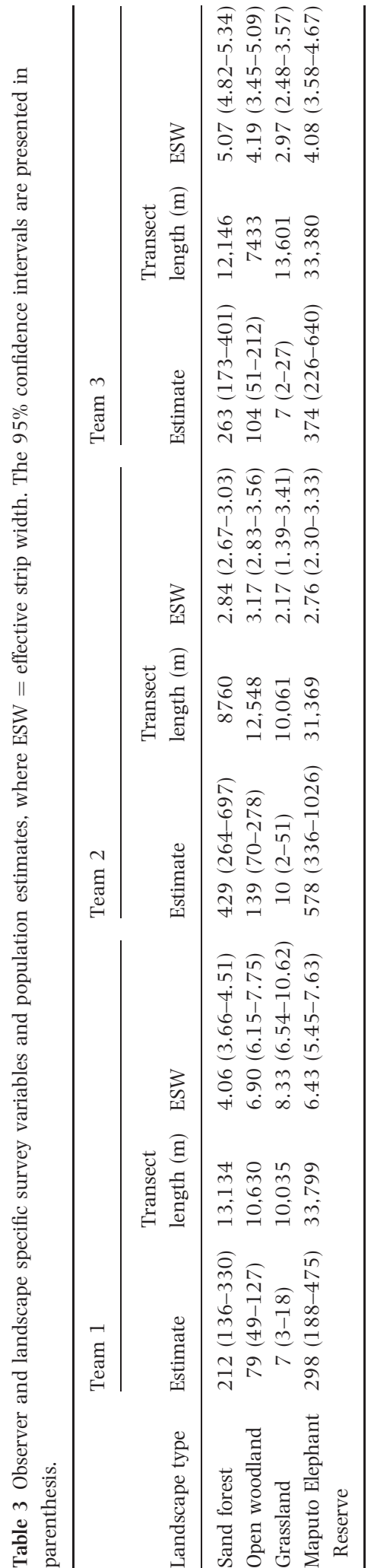

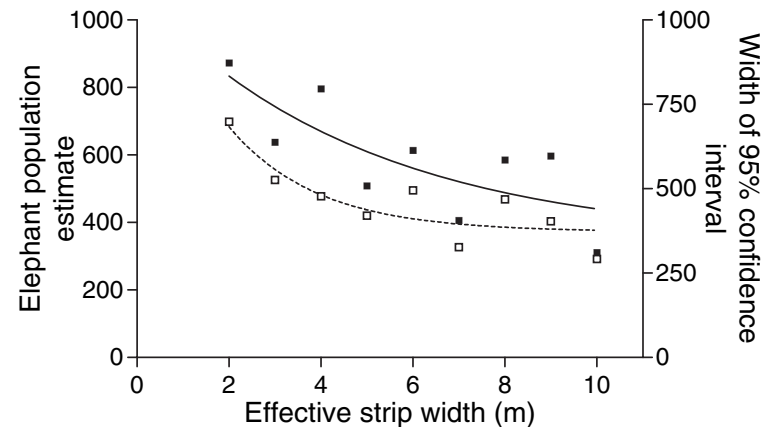

Fig 2 Population estimates (filled squares and solid line) and their 95\% confidence intervals (open squares and broken line) as a function of effective strip widths. The lines were fitted for illustrative purposes using nonlinear regression analyses
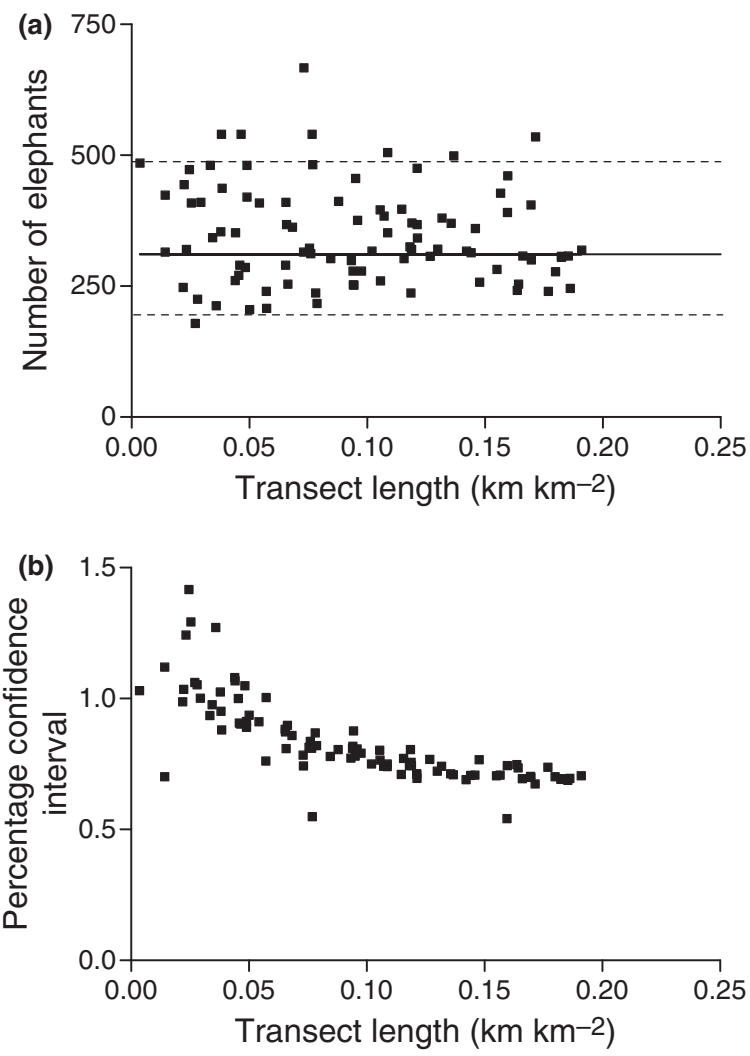

Fig 3 (a) Relationship between sampling intensity (transect length) and the number of elephants estimated in the Maputo Elephant Reserve. The solid line indicates our total estimate of 311 and the broken lines indicate the 95\% confidence intervals (198490). (b) Relationship between sampling intensity (transect length) and the percentage confidence levels for 100 randomly selected analyses and estimates performed by Distance 
into a power analysis suggests that yearly elephant dung surveys for 10 years will only detect relatively large changes (e.g. 5\% annual increase or decrease) with high power (>80\%). Surveys every second year for 10 years will only detect relatively large declines (e.g. 5\% annual decrease). By doubling the monitoring period to 20 years, annual surveys will detect a $2 \%$ yearly increase in population size, whereas surveys every second year may detect annual declines of $2 \%$. Monitoring programmes that last 30 or 40 years may detect such changes with surveys at 5-year intervals (Figs 4 and 5).

\section{Age structure}

Only one of the four surveys yielded a sample size $(\mathrm{n}=158)$ that was large enough for analysis (see Caughley, 1977). Relatively few elephants less than 3 years of age were noted and the age structure seemed uneven (Fig. 6).

\section{Discussion}

The small elephant population of the Maputo Elephant Reserve and their secretive nature hinder attempts to

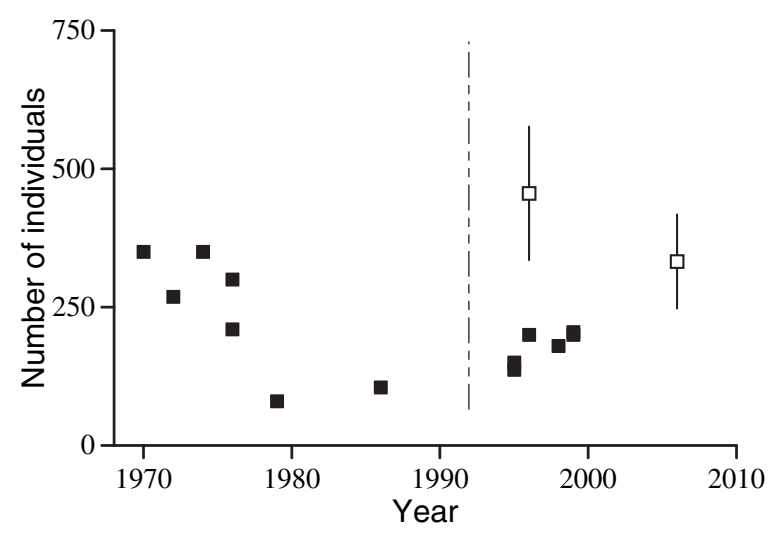

Fig 4 The number of elephants living in the Maputo Elephant Reserve. Solid squares indicate estimates from aerial counts and educated guesses. No confidence intervals were reported for these estimates. The broken vertical line indicates the end of the Mozambican civil war in the early 1990s. To the left of the broken line, the squares indicate a population decline during and preceding the Mozambique civil war. The squares to the right suggest a population recovery after that disturbance. Open squares indicate estimates with 95\% confidence intervals derived from our own dung survey (2006) and the 1995 study by De Boer et al. (2000). [Information from De Boer et al. (2000), Ntumi (2002) and Morley (2006)] estimate population size and structure. We estimated that 311 elephants lived in the MER during 2006. Twelve previous estimates of elephant population size in the reserve varied from 80 to 350 individuals (Morley, 2006). The population was estimated at 350 elephants in 1970 (Tello, 1973), 269 in 1972 (Tinley \& Dutton, 1973) and 80 in 1979 (Klingelhoefer, 1987). The onset of the Mozambique civil war in 1979 prohibited surveys during this period (but one guess by Tello, 1986) and raised fears that the population would be influenced. Since 1995, four surveys reported estimates that ranged from 100 to 300 elephants, suggesting that elephant numbers increased since 1979 (Morley, 2006). However, none of these estimates had measures of precision and were either based on total counts during aerial surveys, or educated guesses.

Given the limitations of the historical data, we opted to estimate the number of elephants using indirect surveys. We do concede, however, that the use of an indirect method such as a dung count has sources of error other than that related to elephant behaviour or small populations. Therefore, we evaluated these and determined what their effect would be on our estimates.

The first thereof is the assumption that the elephants of the MER defecate at the mean wet season rate noted for other regions in Africa. Defecation rate is determined by the quality and quantity of food consumed (Coe, 1974), which differs from season to season. As the MER does not experience much seasonal changes in rainfall that relate to vegetation changes (Van Wyk \& Smith, 2001), we assumed that a mean wet season defecation rate for the elephants here were the same as elsewhere.

A second source of error is dung decay, a process influenced by a variety of factors, principally dung beetle activity and precipitation (Jachmann \& Bell, 1984; Barnes \& Barnes, 1992). Decay rates also vary typically according to season, weather, habitat, diet, canopy cover and time of day of defecation (Nchanji \& Plumptre, 2001; Laing et al., 2003). We monitored dung piles for a period of 148 days under conditions prevailing in the park - more than half of the dung piles then decayed to an unrecognizable state.

For practical reasons, we could not sample reed beds. Therefore, the exclusion of reed beds from our analysis could be a further source of error to our estimate. However, space and habitat use of five elephants based on locations through satellite tracking showed that they spent $<3 \%$ of their time in the reed beds that make up one-third of the MER (Harris et al., 2008). Consequently, we assumed that our estimate would not be affected by us not having sampled the reed beds. 

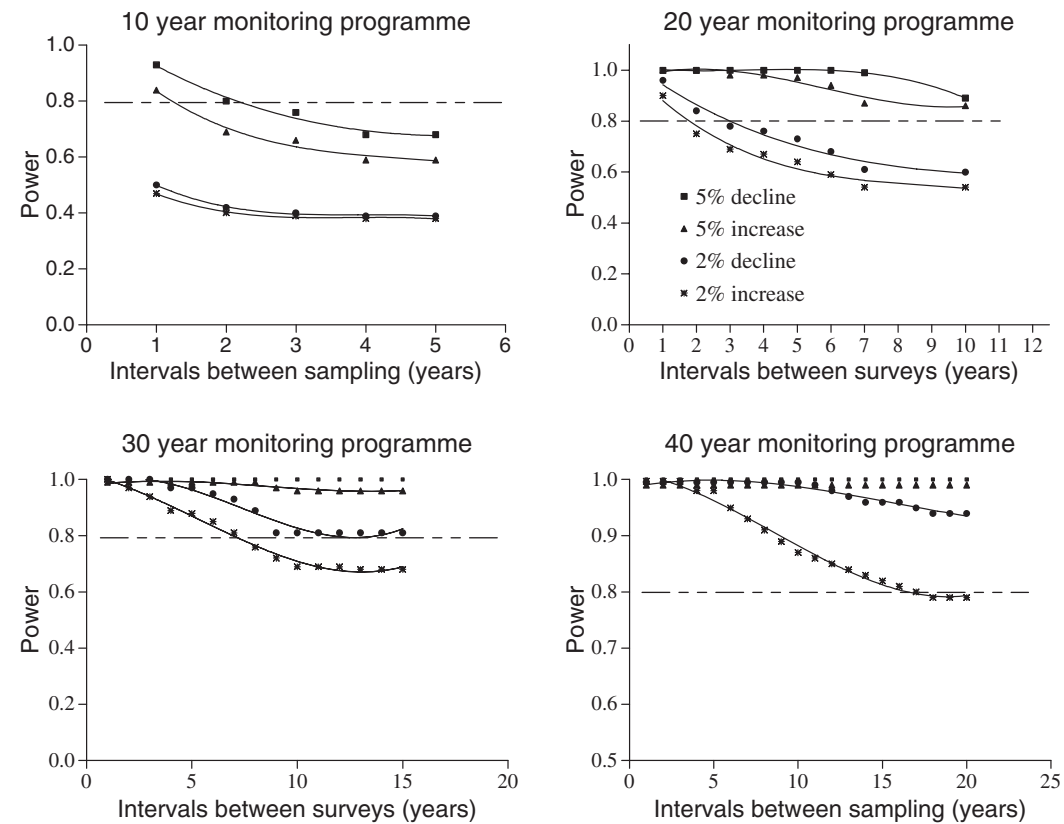

Fig 5 The ability to detect a $2 \%$ and $5 \%$ annual increase or decrease in population size as a function of the frequency of surveys. The broken line indicates $80 \%$ power $(1-\beta)$ and the curves were based on the linear model with $\mathrm{CV}=46.95 \%$ and $\alpha=0.2$

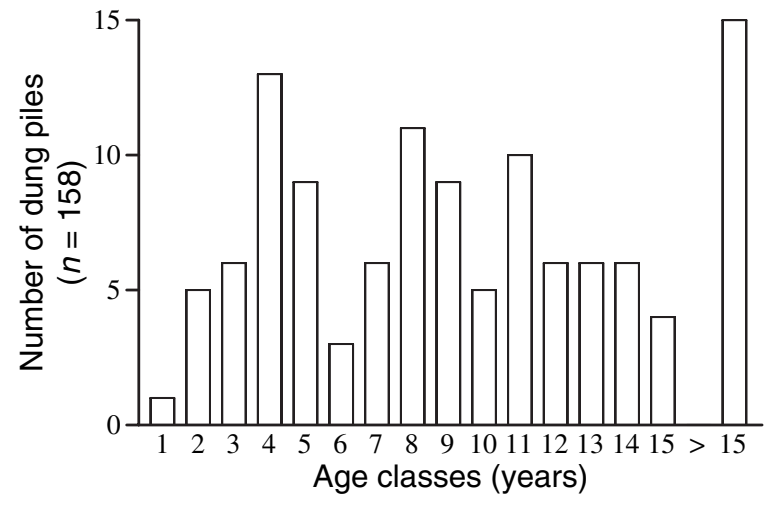

Fig 6 The age distribution for the elephant population in the Maputo Elephant Reserve based on measurements of dung boli circumference. The value in brackets indicates the number of dung piles found during a survey in August 2006

Boli size, observer bias and sampling intensity may induce errors that will influence estimates based on dung surveys. We showed that detectability of small and large boli was similar, but our observers missed 3\% to 19\% of dung piles. The effective strip width also differed between observers - narrow strip widths inflated estimates and vice versa. Strip widths also influenced confidence intervals. Consequently, we consider observer bias as a major source of error in our study.

In our study, the level of precision did not improve with survey intensity once the total transect length exceeded $\sim 51 \mathrm{~km}$. Future dung surveys in the MER may therefore be based on about $50 \mathrm{~km}$ of line transects comprising 100 transects of $500 \mathrm{~m}$ each.

Considering the potential short-comings of our approach, our estimate had a defined precision that lacked in most earlier total counts and guesses. Our estimate exceeded most other recent estimates. The previous estimates may be correct, suggesting that elephant numbers did reach low levels then. People abandoned the area during the war years (Soto, Munthali \& Breen, 2001) so that less than 1000 people lived in the MER during the mid-1990s compared with 10,000 before the war (Ogelthorpe, 1997; Morley, 2006). Such a decline could have facilitated the recovery of the elephant population.

Alternatively, the difference in estimates may not reflect on real changes in population size, but may be because of different survey methodologies returning different estimates. The dung survey by De Boer et al. (2000) in 1995 yielded data comparable with ours, even though they focused on roads rather than randomly placed transects. As in our study, they found that the sand forest had the highest dung pile density, followed by the open woodlands and grasslands. Applying the defecation and decay rates from our study to the dung densities of De Boer et al. (2000) gave an estimate of 425 elephants living in the MER during 1995. This could suggest a recent decline in elephant numbers. However, because of wide confidence, 
limits the change in numbers from 1995 to 2006 was not significant. The population therefore may be stable, as supported by the few infant dung boli noted during our survey.

In addition, retrospective modelling by Morley (2006) suggested that the earlier estimates of Klingelhoeffer (1987) and Matthews (2000) were wrong. The population may have declined during the period of civil unrest in Mozambique, but it may not have been as threatened as was feared at the time (Klingelhoeffer, 1987; Hall-Martin, 1988; Ostrosky, 1989; Morley, 2006).

When we examined the age structure of the MER, we noticed few individuals in the 1-, 2- and 3-year age classes when compared to the rest. Age structures that have been constructed by measuring dung boli are prone to errors presented by the method. The age structure constructed for the elephant population by Jachmann \& Bell (1984) in Kasungu National Park in Malawi also lacked young calves. They proposed three explanations. First, newborn calves could have a lower defecation rate than the older individuals - the published literature does not support this notion (Coe, 1974). Second, small boli decay faster than larger boli - we found no difference in the decay rates at the MER. Third, the droppings of newborn calves are small and are therefore not detected by the counting teams - we found no difference in detection rates in our study. Furthermore, when grouped into broader age classes (following Jachmann \& Bell, 1984), there was still a significant shortcoming of younger individuals. We thus suggest that the marked under-representation of young calves in our sample is not because of sampling error and that there were few juvenile elephants aged 1-3 years in the population.

The uneven age structure for the elephants in the MER may be a result of a population that experienced some or other form of disturbance and this apparent unstable age structure prohibits estimates of survival rate (Udevits \& Ballachey, 1998) and hence modelling of intrinsic growth using demographic variables and procedures proposed by Ferreira \& Van Aarde (2008).

The precision of population estimates in a time series determines the ability to detect trends (Gerrodette, 1987). Our power analyses aimed to direct the intensity of future survey efforts and we recommend that a dung survey be carried out every other year for a 20-year time period. This approach will enable us to confidently detect $2 \%$ per year changes in population growth rates and therefore can facilitate the development of management strategies.
Precision is only one of the criteria to be considered when developing survey procedures as survey intensity may be limited by budgetary and logistical constraints. An aerial survey of the MER would require observers to cover the entire reserve simply because it is small (e.g. DouglasHamilton, 1996; Ntumi et al., 2005) and because the population is relatively small. What is more, estimates of small populations have a low level of precision (Gerrodette, 1987). This may best be addressed for elephants using dung surveys (Barnes, 2002). Like aerial surveys, registration studies (e.g. Whitehouse \& Hall-Martin, 2000; Moss, 2001) and mark-recapture techniques (e.g. Morley \& Van Aarde, 2007) through observation are limited by the secretive habit of these elephants. Individual identification of dung through genetic techniques (e.g. Eggert, Eggert \& Woodruff, 2003) may enable the application of mark-recapture models to improve the precision of estimates.

In addition to cost-efficiency, easily applied techniques also carry the potential to build capacity at a local scale. For instance, our recommendation of repeated surveys over an extended period can include local field rangers participating in surveys. Supplementary data (e.g. age structures) obtained during dung surveys combined with field observations of activities such as poaching (Walsh \& White, 1999) could tilt the cost-benefit of surveys in favour of indirect methods.

\section{Conclusion}

Dung surveys yield population estimates with known precision that could be used in monitoring programmes aimed at assessing population trends. However, these estimates can be affected by observer bias. The similar dung pile densities found by De Boer et al. (2000) and our own in 2006 suggest that the elephant population of the MER is most likely stable. Furthermore, the age structure derived from dung boli circumference compares well with age structures of other known age elephant populations bar the lack of 1-3 year old elephants. Future dung pile surveys at 2-year intervals may shed further light on the dynamics of this relatively small and secretive elephant population.

\section{Acknowledgements}

A grant provided by MOZAL Community Development Trust funded the study. The National Directorate for Conservation Areas (DNAC) authorized the study through 
a MOU between the Universidade Eduardo Mondlane and CERU. Robert Guldemond, Jo Fourie, 'DG' Erasmus, Ferdi Myburgh, Chris Oosthuizen, Zarina Motala, Adrian Haagner, Antoinette van Wyk, Michael Otsub, Daleen Funston and Elsabe Templeton assisted with fieldwork.

\section{References}

BARNES, R.F.W. (1982) Elephant feeding behaviour in Ruaha National Park. Afr. J. Ecol. 20, 123-136.

BARNES, R.F.W. (2001) How reliable are dung counts for estimating elephant numbers? Afr. J. Ecol. 39, 1-9.

BARNES, R.F.W. (2002) The problem of precision and trend detection posed by small elephant populations in West Africa. Afr. J. Ecol. 40, 179-185.

BARNES, R.F.W. \& BARNES, K.L. (1992) Estimating decay rates of elephant dung-piles in forest. Afr. J. Ecol. 30, 179-185.

BARNES, R.F.W. \& JeNSEN, K.L. (1987) How to count elephants in forests. IUCN Afr. Elephant and Rhino Specialist Group Tech. Bull. 1, 1-6.

Barnes, R.F.W., Beardsley, K., Michelmore, F., Barnes, K.L., Alers, M.P.T. \& BLom, A. (1997) Estimating forest elephant numbers with dung counts and a geographic information system. J. Wildl. Manage. 61, 1384-1393.

Barnes, R.F.W., Asamoah-Boateng, B. \& Agyei-Ohemeng, J. (2006) The survival of elephant dung piles in relation to forest canopy and slope in southern Ghana. Pachyderm 41, 37-43.

CAughley, J. (1977) Analysis of Vertebrate Populations. John Wiley \& Sons Ltd., London.

CoE, M. (1974) Defecation by African elephants. East Afr. Wildl. J. $10,165-174$.

De Boer, W.F. \& Ntumi, C.P. (2001) Elephant crop damage and electric fence construction in the Maputo Elephant Reserve, Mozambique. Pachyderm 30, 57-64.

De Boer, W.F., Ntumi, C.P., Correia, A.U. \& Mafuca, J.M. (2000) Diet and distribution of elephant in the Maputo Elephant Reserve, Mozambique. Afr. J. Ecol. 38, 188-201.

Direccao Nacional de Florestas e Fauna Bravia. (1997) Plano de Maneio de Florestas e Fauna Bravia. Maputo, Mozambique, Unpublished report.

Douglas-Hamiton, I. (1996) Counting elephants from the air total counts. In: Studying Elephants (Ed. K. Kangwana). African Wildlife Foundation Technical Handbook Series 7, Nairobi.

EdWards, A.W.F. (1972) Likelihood. Cambridge University Press, Cambridge.

Eggert, L.S., Eggert, J.A. \& Woodruff, D.S. (2003) Estimating population sizes for elusive animals: the forest elephants of Kakum National Park, Ghana. Mol. Ecol. 12, 1389-1402.

Ferreira, S.M. \& VAN Aarde, R.J. (2008) A rapid method to estimate population variables for African elephants. J. Wildl. Manage. 72, 822-829.

GenTLE, J.E. (1943) Random Generation and Monte Carlo Methods. Springer-Verlag, New York.
GERRODETTE, T. (1987) A power analysis for detecting trends. Ecology 68, 1364-1372.

GERRODETTE, T. (1993) TRENDS: software for a power analysis of linear regression. Wildl. Soc. Bull. 21, 515-516.

GibBs, J.P., Droege, S. \& Eagle, P. (1998) Monitoring populations of plants and animals. Bioscience 48, 935-940.

Guldemond, R. \& VAn Aarde, R.J. (2007) The impact of elephants on plants and their community variables in South Africa's Maputaland. Afr. J. Ecol. 45, 327-335.

Hall-Martin, A.J. (1988) Comments on the Proposed Fencing of the Northern Boundary of Tembe Elephant Park. Report to the Kwazulu Bureau of Natural Resources, Ulundi, South-Africa.

Harris, G.M., Russell, G.J., Van Aarde, R.J. \& Pimm, S.L. (2008) Rules of habitat use by elephants Loxodonta africana in Southern Africa: insights for regional management. Oryx 42, 66-75.

Hood, G.M. (2005) Pop tools, version 2.6.6. http://www.cse. csiro.au/poptools

JachmanN, H. (1991) Evaluation of four survey methods for estimating elephant densities. Afr. J. Ecol. 29, 188-195.

JachmanN, H. \& BeLL, R.H.V. (1984) The use of elephant droppings in assessing numbers occupance and age structure: a refinement of the method. Afr. J. Ecol. 22, 127-141.

JefFerson, H.S., Inogwabini, B-I., Williamson, E.A., OMARI, I., SiкubWabo, C. \& White, L.J.T. (1997) A survey of elephants in the Kahuzi-Biega National Park lowland sector and adjacent forests in eastern Zaire. Afr. J. Ecol. 35, 213-223.

Kinahan, A.A., Pimm, S.L. \& Van Aarde, R.J. (2007) Ambient temperature as a determinant of landscape use in the savanna elephant. J. Therm. Biol. 32, 47-58.

KLingelHoeffer, E.W. (1987) Aspects of the Ecology of the Elephant, and a Management Plan for the Tembe Elephant Reserve in Tongoland, Kwazulu. MSc Thesis, University of Pretoria, Pretoria, South Africa.

KüPer, W., Sommer, J.H., Lovett, J.C., MutKe, J., Linder, H.P., Beentjie, H.J., Van Rompaey, R.S.A.R., Chatelain, C., Sosef, M. \& BARтнLотт, W. (2004) Africa's hotspots of biodiversity redefined. Ann. Mo. Bot. Gard. 91, 525-535.

Laing, S.E., Buckland, S.T., Burn, R.W., Lambie, D. \& Amphlett, A. (2003) Dung and nest surveys: estimating decay rates. J. Appl. Ecol. 40, 1102-1111.

Liтorho, M. (2003) An elephant dung survey of the Shimba Hills Ecosystem, Kenya: implications for management. Pacyderm 35, $71-76$.

MatThews, W.S. (2000) Large Herbivore Population Estimates for Tembe Elephant Park. Kwazulu-Natal Nature Conservation Services, Pietermaritzburg, South-Africa. Unpublished report.

MERTZ, G. (1986) Counting elephants in tropical rain forests with particular reference to the Tai National Park, Ivory Coast. Afr. J. Ecol. 24, 61-68.

MorLEy, R.C. (2006) The Demography of a Fragmented Population of the Savanna Elephant in Maputaland. PhD Thesis, University of Pretoria, Pretoria, South Africa.

Morley, R.C. \& VAN AARDE, R.J. (2007) Estimating abundance for a savanna elephant population using mark-resight methods: a 
case study in Tembe Elephant Park, South Africa. J. Zool (Lond.) 271, 418-427.

Morrison, T.A., ChiYo, P.I., Moss, C.J. \& AlberTs, S.C. (2005) Measures of dung bolus size for known age African elephant: implications for age estimation. J. Zool. (Lond.) 266, 89-94.

Moss, C.J. (2001) The demography of an African elephant population in Amboseli, Kenya. J. Zool. (Lond.) 255, 145-156.

Mubalama, L. \& Sikubwabo, C. (2002) Rate of decay of elephant dung in the central sector of Parc National des Virunga, Democratic Republic of Congo. Pachyderm 33, 43-48.

Nchanji, A.C. \& Plumptre, A.J. (2001) Seasonality in elephant dung decay and implications for censusing and population monitoring in south western Cameroon. Afr. J. Ecol. 39, 24-32.

NTumi, C.P. (2002) Space and Habitat Use by Elephants (Loxodonta africana) in the Maputo Elephant Reserve, Mozambique. MSc Thesis, University of Pretoria, Pretoria, South Africa.

Ntumi, C.P., Van Aarde, R.J., Fairall, N. \& De Boer, W.F. (2005) Use of space and habitat by elephants in the Maputo Elephant Reserve, Mozambique. S. Afr. J. Wildl. Res. 35, 139-146.

Ogelthorpe, J. (1997) Management Plan Maputo Special Reserve (1997-2001). Plano de Maneio de Florestas e Fauna Bravia Maputo, Mozambique: Unpublished report.

Ostrosky, E.W. (1989) Monitoring of Elephant Movements Across the International Border between South Africa and Mozambique in the Tembe Elephant Park. KwaZulu Bureau of Natural Resources, Ulundi, South Africa. Third Annual Report. Unpublished report. ReiLly, J. (2002) Growth in the Sumatran elephant and age estimation based on dung diameter. J. Zool. (Lond.) 258, 205-213.

Ruggiero, R.G. (1992) Seasonal forage utilization by elephants in central Africa. Afr. J. Ecol. 30, 137-148.

SHORT, J.C. (1983) Density and seasonal movements of elephants in Bia National Park, Ghana. Afr. J. Ecol. 21, 175-184.

SOKAL, R.R. \& RoHLF, F.J. (1995) Biometry: The Principles and Practice of Statistics in Biological Research. W.H. Freeman and Company, New York.

Soto, B., Munthali, S.M. \& BreEn, C. (2001) Perceptions of the forestry and wildlife policy of local communities living in the Maputo Elephant Reserve, Mozambique. Biodivers. Conserv. 10, 1723-1738.
TснамвA, M.N. (1992) Defecation by the African forest elephant in the Santchou Reserve, Cameroon. Mammalia 56, 155-158.

TelLo, J.L.P.L. (1973) Reconhecimendo ecologico da Reserva dos Elefantes do Maputo. Vet. Mozam. 5, 99-122; 6, 1976; 6, 133186.

Tello, J.L.P.L. (1986) Wildlife in Mozambique: Current Status and Problems. Report to World Wide Fund for Nature, Maputo, Mozambique.

Theuerkauf, J. \& Ellenberg, H. (2000) Movements and defecation of forest elephants in the moist semi-deciduous Bossemati Forest Reserve, Ivory Coast. Afr. J. Ecol. 38, 258-261.

Thomas, L., LaAke, J.L., Strindberg, S., Maroues, F.F.C., Buckland, S.T., Borchers, D.L., ANderson, D.R., Burnham, K.P., Hedley, S.L., Pollard, J.H., Bishop, J.R.B. \& Marques, T.A. (2005) Distance 5.0 Release 2. Research Unit for Wildlife Population Assessment, University of St. Andrews, UK.

Tinley, K.L. \& DutTon, T.P. (1973) Aerial Survey at the Maputo Elephant Reserve. Lourenço Marques, Moçambique: Unpublished report.

UdEvits, M.S. \& BALLACHEY, B.E. (1998) Estimating survival rates with age-structure data. J. Wildl. Manage. 62, 779-792.

VAN WYK, A.E. \& SMith, G.F. (2001) Floristic and Succulent Riches in southern Africa: A Review of Centres of Endemism. Umdaus Press, South Africa.

WaLsh, P.D. \& White, L.J.T. (1999) What it will take to monitor forest elephant populations. Conserv. Biol. 13, 1194-1202.

WHITE, L.J.T. (1995) Factors affecting the duration of elephant dung piles in rain forest in the Lopé Reserve, Gabon. Afr. J. Ecol. 33, 142-150.

Whitehouse, A.M. \& Hald-Martin, A.J. (2000) Elephants in Addo Elephant National Park, South-Africa: reconstruction of the population's history. Oryx 34, 46-55.

Wing, L.D. \& Buss, I.O. (1970) Elephants and forests. Wildl. Monogr. 19, 1-92.

(Manuscript accepted 16 April 2008)

doi: 10.1111/j.1365-2028.2008.00983.x 